European journal of American studies

\title{
(Un)homely Dwellings: The Usher House and the Collyer Mansion
}

Theodora Tsimpouki

\section{(2) OpenEdition \\ Journals}

Electronic version

URL: https://journals.openedition.org/ejas/12063

DOI: $10.4000 /$ ejas. 12063

ISSN: 1991-9336

Publisher

European Association for American Studies

Electronic reference

Theodora Tsimpouki, "(Un)homely Dwellings: The Usher House and the Collyer Mansion", European journal of American studies [Online], 12-2 | 2017, document 8, Online since 01 August 2017, connection on 10 July 2021. URL: http://journals.openedition.org/ejas/12063 ; DOI: https://doi.org/10.4000/ejas. 12063

This text was automatically generated on 10 July 2021 .

Creative Commons License 


\title{
(Un)homely Dwellings: The Usher House and the Collyer Mansion
}

\author{
Theodora Tsimpouki
}

Bring the outside of the world into the house, and
let the inside of the house go outside.
Frank Lloyd Wright, "Building the New House" (1943)

Scholars have long noted the influence of Edgar Allan Poe on E. L. Doctorow's work-an indebtedness that Doctorow himself readily acknowledged. This discussion, however, tends to focus on Doctorow's early writing, while Doctorow's appropriation of Poe in his late work remains largely underdiscussed. The echoes of Poe's "The Fall of the House of Usher" (1839) in Doctorow's penultimate novel, Homer \& Langley (2009), have been all but ignored, with the exception of Christopher Benfey's review of the work, in which he identified the Collyer mansion's “family resemblance to Usher's doomed abode" (Benfey). This article is a first attempt to redress that gap in Doctorow scholarship. In what follows, I will explore the resemblances between the novel and the tale, focusing specifically on their shared interest in notions of home and domesticity that transcend the social norms and values of an increasingly urban America. I will compare Roderick Usher's "mansion of gloom," among the most memorable of Poe's dark, many-chambered mansions, with Doctorow's depiction of the "dark and decaying" (Doctorow, Homer \& Langley 205) New York brownstone of the infamous Collyer brothers.

2 The brothers in Doctorow's novel are fictionalized versions of Homer and Langley Collyer, New Yorkers who gained a legendary status due to their eccentric hoarding practices and reclusiveness. The two brothers spent their entire lives in their family home in Harlem, at the corner of Fifth Av. and 128th St., leaving the neighborhood only to collect junk off the street, and thus becoming something of a local curiosity. Public interest in them intensified after their deaths, in 1947, when their bodies were discovered in their mansion, buried underneath the mounds of hoarded junk they had amassed over several decades. It transpired that Langley, the elder brother, had died of asphyxiation when a tunnel he had built in the trash collapsed on him. Homer subsequently died of malnutrition, having no one to feed him. ${ }^{\mathrm{i}}$ 
3 However, Doctorow's narrative departs from the historical reality of the Collyer brothers' lives in its chronology. In expanding their story to cover the twentieth century in its entirety-from the early 1910s to the late 1990s-Doctorow is able to explore the elements of home and domesticity and their shaping of psychic life and belonging in relation to a shifting cultural landscape. In this way, the novel traces the disturbing relationships between urban space and subjectivity, as well as individual freedom and consumer capitalism across an entire era. Doctorow deftly manipulates Poe's favorite gothic connection between architectural construction and the psychological experience of characters to reimagine the lives of the Collyers, whose self-imposed incarceration is experienced as an act of autonomy and selfdetermination, and contrasts sharply with the mundane prosperity and social conformity championed by modern American consumer culture. ${ }^{\text {ii }}$

4 Most importantly, in Doctorow's novel, the Collyer brothers are not the obsessed hoarders or the models of American consumerism par excellence, as the urban legend describes them. On the contrary, they become paradigms of dwelling with alertness in the Heideggerian sense, resisting the instrumentalist modes of thought and responding non-masteringly to hoarded things; that is, letting themselves and the world be rather than seeking to dominate the world to their own ends. ${ }^{\text {iii }}$ According to the German philosopher, this comportment toward material objects reveals itself as "releasement toward things," as "letting beings be," that is, opening up the possibility of relying on things while not becoming enslaved to them. In Doctorow's words, the notorious recluses of Fifth Avenue "opted out of civilization and pulled the world in after them," choosing this paradoxical way of dwelling to counter an encroaching modernity (Ciabattari). Further, the Collyer house as presented by Doctorow assumes qualities akin to Gaston Bachelard's concept of the oneiric house, a space that becomes the "center of condensation of intimacy, in which daydream accumulates" (29). This kind of house is not "an inert box" (47) confined by physical boundaries; not only does it enter into an unpredictable relation with the material world, but it elicits the potentiality to open up toward the world beyond. Thus, in Doctorow's fictive rendering of the Collyer house, Usher's ghostly mansion is converted from a totally enclosed cell, sealed off from its urban surroundings, to a place characterized by the porosity and openness typical of urban living spaces. This transformation ineluctably generates a multifaceted connection with the outside world. Through the reconfiguration of certain aspects of Poe's seminal story and appropriation of the life-story of the hermit brothers, Doctorow's Homer \& Langley explores the concepts of dwelling and domesticity as they relate to the geophysical and psychic landscape of an American metropolis in flux.

5 Doctorow's relation to Poe was very personal. Indeed, he noted in several interviews that his father had christened him Edgar after the poet. Although Poe seems to have failed to meet Doctorow's standard of public engagement, as he showed "little sympathy for the idea of a democratic republic," Poe's specter looms large over Doctorow's oeuvre ("Our Edgar" 18). As he admits in his 2006 essay on Poe, "Edgar Allan Poe, that strange genius of a hack writer, lived in such a narcissistic cocoon of torment as to be all but blind to the booming American nation around him, and so, perversely, became a mythic presence in the American literary consciousness" (11). Still, "from the sealed crypt of his own brain," Poe, in Doctorow's words, responds in an idiosyncratic yet powerful way to the "idealistic secular democracy of a fearlessly self-renewing America" (Reporting 120, 108). 
6 References to Poe abound in Doctorow's fiction, as well. A lengthy allusion to the poet features in The Book of Daniel, Doctorow's widely acclaimed third novel, which is a fictional exploration of the controversial case of Julius and Ethel Rosenberg. Here, the disillusioned protagonist, Daniel, calls Poe an "archetype traitor," "that scream from the smiling face of America," "who wore a hole into the parchment and let the darkness pour through" (177). Doctorow's Daniel considers Poe "the master subversive," who upsets the optimistic spirit of the American Dream. ${ }^{\text {iv }}$ Poe, likewise, surfaces in Doctorow's mid-1990s novel, The Waterworks, which is considered his "Poesque novel of detection" (Gentry 64). Doctorow made these connections explicit in an interview, terming the novel "his homage to his namesake" (Graeber). Elsewhere, he describes The Waterworks as "a dark tale that participates in nineteenth-century storytelling conventions staked out by Melville and Poe. It's a mystery of sorts, a scientific detective tale" (Wachtel 187). Indeed, the novel has elements of Poe in its combined interest in science and detection, its detective-story structure, its fascination with the crossover between life and death, and its narrator who defends his reliability. Poe and the gothic tradition are deployed to provide "an ironic commentary on the American dream and a postmodern meditation on language, authorship, history, and epistemology-all within the form of the metaphysical detective story" (Diemert 352).

Of Doctorow's entire oeuvre, Homer \& Langley is, to my mind, the novel most indebted to Poe and, in particular, to his literary masterpiece, "The Fall of the House of Usher." In "The Fall of the House of Usher," Poe posits the house as a "psychological space," relating the physical decay of the titular building's structure and its claustrophobic interior to the psychological dislocation of its inhabitants. In Daniel Hoffman's words, the story is a "journey into the darkest, most hidden regions" of the mind (297) or as Anthony Vidler remarked, a "domesticated version of absolute terror" (3). ${ }^{\mathrm{v}}$ In Homer \& Langley, Doctorow deliberately evokes Gothic conventions in order to present-through the withdrawn, supposedly "insane" lives of the Collyers-an interior life that longs for self-realization and freedom from social constraints, the embodiment of an escapist mentality in a culture driven by mundane prosperity and social compliance. In this sense, the Collyer house can be considered as the lived space in which the brothers literally "ground" themselves in order to enact what Heidegger calls "meditative thinking" against the threat of calculative and manipulative modes of thought which seem to be favored in the modern world. Having this comportment, the German philosopher says, allows "the possibility of dwelling in the world in a totally different way" (55). ${ }^{\text {vi }}$ In turn, their disintegrating home, much like the ruins described by Tim Edensor, entirely rebukes capitalist notions of endless progress. The house critiques what Edensor describes as the "ways in which urban space is produced and reproduced" (17), while at the same time it constitutes an essential resistance to "normative aesthetic orderings" (76). Comparing the two houses, then, we might conclude that while the Usher house inflicts terror and discomfort to both insiders and outsiders, the Collyer house disgusts outsiders, but in fact cradles and protects its inhabitants. Like Edensor's ruins, the house, in its decaying, crumbling condition, can be seen to open a wider crack "in the façade of seamless homogeneity erected by society" (58)-even more so if we take into consideration its location, which Doctorow changes from Harlem to the expensive district of Upper East Side. ${ }^{\text {vii }}$

8 The affinities between Doctorow's and Poe's texts are also evident at the formal level: just as "The Fall of the House of Usher" is narrated by the protagonist who is also a 
character in the story, Homer \& Langley is narrated by one of the two Collyer brothers, Homer, as he approaches the end of his life. The opening line of the novel, "I'm Homer, the blind brother," establishes Homer's intuitive and contemplative consciousness as a counter to Langley's skeptical disillusionment, and as a central force to the narrative. His loss of sight and, eventually, hearing renders him the more vulnerable of the two brothers and forces him to retreat into the comforting confine of the home. Langley, in turn, becomes his brother's devoted caretaker, assuming the task of nurse, companion and entertainer. The two brothers develop a tremendous psychological connection, reminiscent of the Usher twins. Furthermore, as in Poe's tale, the twin relationship enhances the Gothic effect of the grotesque: in Doctorow's novel the brothers' symbiotic "cling[ing] to one another" (Tokarczyk 91), in a relationship that seemed "more incestuous than fraternal,"viii amplifies the bizarre and uncanny qualities of their social isolation. Fittingly, the song Doctorow chooses to characterize their codependent fraternal relationship is "Me and My Shadow." ${ }^{\mathrm{ix}}$ And, the more Langley continues filling the once attractive home with huge amounts of newspapers, boxes, barrels, books, metal cans and other assorted trash, the more Homer's movement inside the house is obstructed, and the more dependent he becomes on his brother. Homer acknowledges that: "The house by this time of our lives was a labyrinth of hazardous pathways, full of obstructions and many dead ends. With enough light someone could make his way through the zigzagging corridors of newspaper bales, or find passage by slipping sideways between piles of equipment of one kind or another" (158). The symbiotic, near visceral, relationship of the brothers comes to be embodied by the physical matter with which they are surrounded, and which essentially locks them in each other's company.

9 Toward the end of their lives, when all the house's rooms have been filled by a floor-toceiling wall of crates, furniture and odd pieces of junk, Homer's survival literally depends on his brother, who crawls "down" a "tunneled passageway" between "bales of newspaper and overhanging garden tools" to give him his meals (205). As Homer tenderly but helplessly remarks, he is left with "only the touch of my brother's hand to know that I am not alone" (208). Notably, however, the novel does not render explicit the circumstances by which the brothers' "fatally intertwined lives" (Oates) ended (the real-life Langley's death by suffocation after one of his own booby-traps collapsed on him, and his brother's subsequent starvation). Instead, it is alluded to: Doctorow's Homer concludes his memoir with a desperate appeal to Langley: "Where is Langley? Where is my brother?" (208). Homer's final words point to the extraordinarily strong bond with his brother and bring the novel full circle. The opening and the closing lines of the novel establish the contours of the brothers' existence. In one reviewer's apt expression, "the two men come to constitute each other's world" (Kakutani)becoming, in essence, each other's spiritual home.

As in Poe's story, the deaths of the two siblings occur nearly simultaneously. ${ }^{x}$ The deaths of Doctorow's Homer and Langley Collyer, like the deaths of Poe's Roderick and Madeline Usher, mark the end of their family lineage (or "house") and are rendered physically by the disintegration of their actual houses. The very title of Poe's story plays on ambiguity, signifying both the collapse of the house that is the Usher family lineage, and the physical structure of the Usher mansion. Roderick himself underscores this connection by noting the merging of "the original title of the estate in the quaint 
and equivocal appellation of the 'House of Usher,'-an appellation which seemed to include...both the family and the family mansion" ("The Fall of the House of Usher").

11 This same theme is taken up in Doctorow's novel, where Homer explicitly echoes Roderick's words. Describing the public's view of them, Doctorow's Homer refers to "the decline of a House, the Fall of a reputable family" (177), a description that uncannily recalls the plight of Poe's characters. This is but one of many resonances with Poe's story. Like the Ushers, the Collyers were part of one of New York's oldest, most respectable families. ${ }^{\mathrm{xi}}$ And like the Ushers, Homer describes himself and his brothers as "end of the line." At the same time however, whether to assuage the fear of imminent death, or perhaps to avoid the bleak association with the Usher family, he then modifies this description, preferring to think of them as "a supreming of the line, a flowering of the family tree" (177) - a designation that recalls Marilynne Robinson's description of Usher, and Poe's aristocrats in general, as being the "always decadent last flowering of an endless lineage" (4). Finally, while the collapse of the physical house following the deaths of the siblings in Poe's story is not echoed in Doctorow's novel, the house of the real Collyer brothers was, in fact, demolished three months after their death. Thus, life uncannily imitated fiction. Since the 1960s, the site of the mansion has been a pocket park, named for the brothers. ${ }^{\text {xii }}$

The novel's recurring emphasis on the Collyer brothers' visceral attachment to their house suggests the merits of reading the space both as an architectural structure and as a spiritual retreat-a physical entity as well as a psychological one. Or better, we might follow Doctorow's directions to imaginatively "break in and enter the house." xiii "The interior of the Usher house repeats its exterior" (Riddel 127). But, while Poe's house in "The Fall of the House of Usher" is depicted in desolate terms from the start, as "an extraordinary dilapidation," a bleak structure, surrounded by wasteland, whose windows stare vacantly at those who approach, the opposite is true of Doctorow's. The house to which the reader is first introduced is magnificent: Homer describes the three-story mansion on upper Fifth Avenue where he and his brother spent their wellupholstered childhood as "a monumental tribute to late Victorian design" that would nevertheless "be bypassed by modernity" (6). It is only following their parents' death and Langley's traumatic experiences fighting in the First World War that the brothers grow estranged from the outside world, that they barricade themselves within the walls of their mansion, and that the mansion itself begins to decay. This process of disintegration has a clear narrative arc, and can be seen as its own story, of which the building is as much a protagonist as its inhabitants. It is both a living creature, vulnerable to time's passage and affected by social change, which it registers physically, and a commodity vulnerable to the whims of the market. In both cases, Doctorow depicts a process of devolution-from "healthy" entity to sick, from valuable commodity to waste. The devolution of the building is as significant as the gradual dissipation of the characters themselves, who repudiate their aristocratic heritage and waste their fortune to eventually become, as Homer describes it, "the ghosts who haunted the house we once lived in" (198). ${ }^{\text {xiv }}$

In this, too, the echoes of Poe's House of Usher resound. The Usher domain is represented as having large rooms with vaulted ceilings and dark draperies, "sombre tapestries" and "phantasmagoric armorial trophies" on the walls, and numerous "dark and rumbling corridors" ("The Fall of the House of Usher"). It is "a clutter of antiquated styles and disrelated objects," Joseph N. Riddel maintains, "a bric-á-brac which can no 
longer signify the stability of the family's estate... or suggest its continuing 'line" (127). Similarly, even before their parents' death, the Collyer abode is depicted already as an "aspiring warehouse" with its "tufted Empire side chairs" and smothering curtains, its medieval tapestries, thick Persian rugs and "standing lamps with tasseled shades and matching chinois amphora that you could almost step into" (6). Nevertheless, though the influence of the Usher house may be detected in Doctorow's depiction of the Collyer house, the two representations are also very different. While the atmosphere of disquiet and distress is deliberately invoked inside the Usher house, the Collyer interior is experienced as "comfortable, solid, dependable" (6). "Cluttered it might have seemed to outsiders," Homer observes, "but it seemed normal and right to us and it was our legacy, Langley's and mine, this sense of living with things assertively inanimate, and having to walk around them" (6-7). Obviously, there exists a lived reciprocity between the inhabitants and the giant amounts of heteroclite objects that surround them, a non-possessive, intimate attachment to them which, in Bachelardian terms, "weaves the ties that unite a very ancient past to the new epoch" (68). This is where Bachelard's conception of "vital space" is useful, for it is a sheltering space, both imagined and concrete, which defines the subject's existence and where thought and daydreaming begin. "We should therefore have to say how we inhabit our vital space," says Bachelard, "how we take root, day after day, in a "corner of the world"" (4). For the Collyers, their house is their "corner of the world," "a real cosmos in every sense of the world" (4).

Barry Curtis succinctly contends that "houses inscribe themselves within their dwellers, they socialize and structure the relations between families, and provide spaces for expression and self-realization in a complex interactive relationship" (34). As a matter of fact, unorthodox as it may seem, the Collyer relationship with the space in which they dwell defines their existence, and makes the world meaningful to them. Although it may not look as the model kind of building and dwelling-in the manner of Heidegger's cabin in the Black Forest or Bachelard's vision of the oneiric house ${ }^{\mathrm{xv}}$-the Collyer house is experienced as a place charged with meanings. Over the decades, they accumulate the debris of consumer culture, the "artifacts of some enthusiasm of the past" (102), which include several pianos, banjos, plaster busts, baby carriages, chandeliers, clocks, rusted bicycles, guns, over 25,000 books, and a lot more, turning their house into a "graveyard of the casualties of progress," as one critic has called it (Secher). Yet, in their opinion, they bring the world into their home like a museum of the grotesque, leaving their "riches as yet uncatalogued, the curating still to come" (102).

Interestingly enough, unlike the real Collyers who develop compulsive hoarding habits, their fictional counterparts adopt a disparaging attitude toward material culture, exhibiting an apathetic disdain for the comfort and pleasures of domestic life. They initiate an imaginative, anarchic response to material goods introducing an alternative, non-proper use for them. They turn the familiar domestic space into a phantasmagoria of the interior by divesting objects of their inherent function, and unconcealing their "promise of the unexpected" (Edensor 4) or granting them an aesthetic value. For example, among other items they have added in their bizarre collection is a complete Model $\mathrm{T}$ Ford, which they install in the dining room. Langley's justification for incorporating a vehicle into their household is that there is "no ontological distinction between outside and inside" (80), thus blurring the boundaries between private domain and public space, the familiar and the uncanny. ${ }^{\mathrm{xi}} \mathrm{He}$ goes on to defend his position 
claiming that the automobile's "hideousness," its "monstrosity," had become apparent when placed in the context of their "elegant dining room." It is with rebellious acts of this sort-incidentally reminiscent of Duchamp's display of the Fountain ${ }^{\text {xvii }}$ as an exhibit piece-that the Collyers attempt to assert their individualism and affirm their existence. As a matter of fact, they both seem eager to engage with the materiality of the world in its excess and alterity, to explore the transformative potential of everyday life. The two brothers seem to embrace "a kind of thinking about everyday life that goes beyond the narrow functionalism and gives importance to different styles and priorities-to spaces, rhythms, objects, and practices," as Michael Sheringham would have it (2). Sheringham adds, following Lefebvre: "everyday life harbours within itself the possibility of its own existential or ontological transformation" (12).

Obviously, Doctorow's Collyer brothers locate freedom in the unnecessary, the inappropriate, and the superfluous, but doing so thrusts them deeper into the realm of the uncanny. For example, they decide at one point to wage war against "the Health and Fire Departments, the Bank, the utilities, and everyone else" (175); at another, they find themselves trying to survive without basic allowances, such as electricity, gas or running water. Disturbing and improbable as this may sound, their behavior is based on historical evidence, ${ }^{\text {xviii }}$ but in Doctorow's narrative it is a self-consciously imposed design, as the Collyers increasingly refuse to participate in a system they passionately believe to be inherently corrupt and immoral. ${ }^{\text {xix }}$ To counter the pressures of the system and live a life of self-sufficiency, Langley grows familiar with the legal system in order to avoid eviction procedures for failing to pay their mortgage $(171,180)$; he also finds an alternative source of lighting when their electricity and gas are disconnected (195). Lastly, with "a kind of boyish excitement" (197), the brothers carry an elaborate routine to obtain water from a public fountain in Central Park when their water services are cut (197). This is one important reason why Doctorow chooses to relocate the historical Collyer house from Harlem to the Upper East Side overlooking Central Park. In this way, the park serves to reproduce in the public realm the private courtyard of the family dwelling of the pre-modern era. In addition, the fact that the park is accessible by foot, rather than by urban transportation, both increases its positive value in their lives and illustrates their antipathy to any kind of technology. "[T]he key thing here was our self-reliance" (196), Homer argues on behalf of his brother, resolved as they both are to keep alive the legacy of radical dissidence deriving from the work of Emerson ${ }^{\mathrm{xx}}$ and Thoreau.

Ironically, neither the Collyers' self-imposed isolation nor the presence of foreign and unintelligible artifacts in the topography of their private space can set them apart from the world. The world intrudes, because even such "principled separatists, recluses" as the Collyers cannot and will not keep the city outside their doorstep. "The doors are bolted and the windows are shuttered, but the 20th century crawls in through the cracks," says one reviewer of the book (Brooks). Thus, over the decades, they turn their home into a safe house for a number of diverse visitors: the ambitious Hungarian maid with whom Homer sleeps, the African-American cook with her talented Jazz-musician nephew, a prohibition-era gangster who later finds refuge in their kitchen chased after the police, the guests who arrive at the "tea dances" the brothers organize during the Depression, the Japanese Nisei couple they employ during WWII, as well as a group of hippies who briefly stay with them. Naturally, there is an elective affinity between the two brothers and the youths who, to the brothers' amazed satisfaction, practice communal living for a month. The Collyers' long hair and unconventional attire, their 
non-conformist attitudes and indifference to material possessions are admired by the youths, who regard them as "prophets of a new age" (142) and "guru[s]" (153), and their house as "a Temple of Dissidence" (146). However, in order to be able to resurrect through the brothers' imagined experience the 1960s youth culture and the antiVietnam War movement, Doctorow moves up the narrative by almost three decades extending their life span into the late 1970s. ${ }^{x x i}$

As one of the great New York fiction writers, a novelist who captures the zeitgeist of the city, Doctorow uses the Collyers' domestic existence as a springboard for exploring the conditions of dwelling in the modern American metropolis. The notion of a purely bounded and fixed domesticity, separated from all surrounding human activities, seems impossible and undesirable within the networks of contemporary urban America, even when it comes to the exaggerated seclusion of the Collyers. Moreover, instead of emphasizing the house's immobility and confinement, Doctorow reinscribes it with a new meaning that becomes liberating. Thus, the Collyer mansion is presented as exhibiting an extroverted interiority, a place which-in spite of its Heideggerian rootedness-is forever challenged by mobility. Small wonder that Doctorow refers to Homer \& Langley "as a road novel-as if they are two people traveling together down a road and having adventures, though in fact they are housebound" (Ciabattari).

The persistent gothic traces present in Homer \& Langley are reworked and rearranged to the effect of destabilizing the very concept of the traditional, heteronormative, capitalist American home. Poe's famous story functions for Doctorow as a platform from which to stage his ontological concern for "being-at-home" and a genuine dwelling that vies with and runs counter to consumer culture and the cult of technological progress: the numbing comfort of urban American domestic spaces, this taken-for-granted domestic familiarity, is in Doctorow's view neither sustainable in the context of a milieu being constantly transformed by urbanization and mass consumption, nor is it desirable.

\section{BIBLIOGRAPHY}

Bachelard, Gaston. The Poetics of Space. Trans. Maria Jolas. Boston: Beacon Press, 1994. Print.

Benfey, Christopher. "The Escape of the Collyers." New York Review of Books, 17 Dec 2009. Web. 20 Aug 2016.

Brooks, Xan. "Doctorow's New York hermits cannot keep the 20th century at bay." The Guardian, 16 Jan. 2010. Web. 20 Aug 2016.

Ciabattari, Jane. “Doctorow's High-Society Hermits.” The Daily Beast, 31 Aug 2009. Web. 7 Sep 2016.

“Collyer Brothers Park.” Historical Signs Project 25 Oct 2000. Web. 23 Dec 2016.

Curtis, Barry. Dark Places: The Haunted House in Film. London: Reaktion Books, 2008. Print. 
Diemert, Brian. “The Waterworks: E. L. Doctorow's Gnostic Detective Story.” Texas Studies in Literature and Language 45.4 (2003): 352-374. Print.

Dini, Rachele. Consumerism, Waste, and Re-Use in Twentieth-Century Fiction. Legacies of the AvantGarde. New York: Palgrave Macmillan, 2016. Print.

Doctorow, E.L. The Book of Daniel. New York: Random House, 1971. Print.

---. The Waterworks. New York: Random House, 1996. Print.

---. Reporting the Universe. Cambridge, MA: Harvard University Press, 2003. Print.

---. “Our Edgar.” Creationists: Selected Essays, 1993-2006. New York: Random House, 2006. Print.

---. “Back Talk. E. L. Doctorow,” The Nation, 12 Oct 2009. Web. 7 Sep 2016.

---. Homer \& Langley. New York: Random House, 2009. Print.

Eagleton, Terry. The Ideology of the Aesthetic. Oxford: Basil Blackwell, 1995. Print.

Edensor, Tim. Industrial Ruins: Space, Aesthetics, and Materiality. New York: Berg, 2005. Print.

“E. L. Doctorow on His New Novel Homer \& Langley." WNYC New York Public Radio. 22 Sep 2009. Youtube. Web. 22 Dec 2016.

Gentry, Marshall Bruce. “The Waterworks as Doctorow's Poesque Preface.” South Atlantic Modern Language Association 67.1 (2002): 63-90. Print.

Graeber, Laurel. “Left Out by Edith Wharton.” New York Times, 19 June 1994. Web. 10 Dec 2016.

Heidegger, Martin. “Building, Dwelling, Thinking." Martin Heidegger: Basic Writings. Ed. David Farrell Krell. London: Routledge, 1993. 347-362. Print.

---. Discourse on Thinking. Trans. John M. Anderson and E. Hans Freund. New York: Harper \& Row, 1966. Print.

Herring, Scott. The Hoarders: Material Deviance in Modern American Culture. Chicago: University of Chicago Press, 2014. Print.

---. “Collyer Curiosa: A Brief History of Hoarding." Criticism 53.2 (2011):159-188. Print.

Hoffman, Daniel. Poe Poe Poe Poe Poe Poe Poe. New York: Avon Books, 1972. Print.

“Homer \& Langley Collyer: Hoarders in Harlem.” 12 Sep 2012. Web. 21 Dec 2016.

https://keithyorkcity.wordpress.com/2012/09/28/homer-langley-collyer-hoarders-in-harlem/ Jarvis, Robert. "The Curious Legal Career of Homer L. Collyer." Journal of Maritime Law and Commerce 38. 4 (2007): 571-582. Print.

Kakutani, Michiko. "How Did They End Up That Way?” New York Times, 1 Sep 2009: C1. Print.

Lefebvre, Henri. The Production of Space. Trans. Donald Nicholson-Smith. Oxford UK \& Cambridge USA: Blackwell, 1991. Print.

Moran, Patrick W. "The Collyer Brothers and the Fictional Lives of Hoarders." MFS Modern Fiction Studies 62.2 (2016): 272-291. Print.

Oates, Joyce Carol. “Love and Squalor.” The New Yorker, 7 Sep 2009. Web. 15 Sep 2016.

Penzel, Fred. "Langley Collyer: The Mystery Hoarder of Harlem.” Western Suffolk Psychological Services, 15 Apr 2011. Web. 20 Dec 2016.

Perry, Dennis R. and Carl H. Sederholm. Poe, "The House of Usher," and the American Gothic. Basingstoke: Palgrave, 2009. Print. 
Poe, Edgar Allan. “The Fall of the House of Usher." Project Gutenberg. Web. 20 Aug 2016.

Riddel, Joseph N. “The ‘Crypt' of Edgar Poe.” boundary 2.3 (1979):117-144. Print.

Robinson, Marilynne. “On Edgar Allan Poe.” The New York Review of Books, 5 Feb 2015. Web. 20 Aug 2016.

Scandura, Jani. Down in the Dumps: Place, Modernity, American Depression. Durham: Duke University Press, 2008. Print.

Sheringham, Michael. Everyday Life: Theories and Practices from Surrealism to the Present. Oxford: Oxford University Press, 2006. Print.

Secher, Benjamin. “Homer \& Langley.” The Telegraph, 25 Jan 2010. Web. 15 Aug 2016.

Tokarczyk, Michelle. "Review." Homer and Langley. Modern Language Studies 39.2 (2010): 90-91.

Print.

Verbeek, Peter-Paul. What Things Do: Philosophical Reflections on Technology, Agency, and Design.

University Park: Pennsylvania State University Press, 2005. Print

Vidler, Anthony. The Architectural Uncanny: Essays in Modern Unhomely. Cambridge, Mass.: The MIT Press, 1992. Print.

Wachtel, Eleanor. “E. L. Doctorow.” More Writers and Company: New Conversations with CBC Radio's Eleanor Wachtel. Toronto: Knopf, 1996. Print.

Weber, Bruce. “E. L. Doctorow Dies at 84; Literary Time Traveler Stirred Past Into Fiction.” New York Times, 21 July 2015: A1. Print.

Wright, Frank Lloyd. “Building the New House." Frank Lloyd Wright: An Autobiography. 1943.

Petaluma, CA: Pomegranate Communications, 2005. 141-144. Print.

\section{NOTES}

i. Patrick W. Moran's recent article entitled "The Collyer Brothers and the Fictional Lives of Hoarders" traces the interrelationship between fictional representations of the brothers and hoarding. Such an account inevitably even if briefly mentions Doctorow's novelization of the brothers' lives.

ii. Scott Herring's 2011 essay, "Collyer Curiosa: A Brief History of Hoarding," and more recently his book-length study on hoarding entitled The Hoarders: Material Deviance in Modern American Culture attempts to explore the historical and cultural conditions that have made the recent psychopathology of hoarding possible. See also Moran.

iii. I am referring to Heidegger's concept of Gelassenheit, as presented in the two essays contained in the Discourse on Thinking (1966). Gelassenheit is "releasement toward things," letting go of willing, crossing from "calculative thinking" which is characteristic of our technological world to "meditative thinking" which allows us to inhabit the world "in a totally different way" $(54,55)$. Responding to Heidegger's notion of a "releasement" of things by which they are "let be" rather than "challenged-forth," Terry Eagleton notes Heidegger's "sense of a meditative 'being-with' things, attending responsively, non-masteringly to their shapes and textures" (310), thus, cultivating new ways of inhabiting the world.

iv. The full reference is as following: [H]istorians of early America fail to mention the archetype traitor, the master subversive Poe, who wore a hole into the parchment and let the darkness pour through. This is how he did it: First he spilled a few drops of whiskey just below the Preamble. To this he added the blood of his thirteen-year-old cousin in Virginia, whom he had 
married and who hemorrhaged from the throat. He stirred these fluids in a small, elliptically stressed circle with the extracted tooth of the dead Ligeia. Then added some raven droppings.... [T]hrough the resulting aperture in the parchment the darkness of the depths rose, and rises still from that small hole all these years incessantly pouring its dark hellish gases like soot, like smog, like the poisonous effulgence of combustion engines over Thrift and Virtue and Reason and Natural Law and the Rights of Man. It's Poe, not those other guys. He and he alone. It's Poe who ruined us, that scream from the smiling face of America (177).

v. A deconstructive interpretation of "The Fall of the House of Usher" (and of Poe's oeuvre in general) is provided by Joseph N. Riddel who reads the "figure of the house, the family, and the story itself" as "fragments" enclosed in a final metaphor-"an infinitely refracted series of fictions without origin or end"(130).

vi. Heidegger's notion of "rootedness in the soil" is frequently associated with the Blut und Boden nostalgia for the homeland. Such a claim moves beyond the scope of this paper, but I would like to agree with Peter-Paul Verbeek who argues that what "matters for Heidegger is not the attachment of a people to its homeland, but rather the relationship that human beings have to their everyday environment" (59).

vii. Doctorow makes significant changes to the historical facts: While the Collyer brothers' brownstone was located in Harlem on the corner of Fifth Avenue and 128th Street when it was still a fashionable white enclave, the fictional house is relocated in the Upper East Side of 5th Av, right across Central Park. Another change is that he reverses the brothers' birth order. According to Trinity Church's baptismal records, Homer Collyer was born in 1881. Langley was four years younger. Both brothers attended Columbia University. Homer earned a law degree, and his younger brother graduated with a degree in mechanical engineering and chemistry. As an adult, Homer worked as an admiralty lawyer, while Langley was the pianist of the family, not Homer. Finally, Doctorow moves up the narrative by almost three decades.

viii. In Down in the Dumps, Jani Scandura writes that the two bachelor brothers "are dependent on each other in a way more incestuous than fraternal" (163). He obviously refers to the real brothers, but Doctorow too underscores the Collyers' extreme interdependency.

ix. "Me and My Shadow," was a 1927 popular song. Homer asks his brother, "Am I your shadow?" to which Langley responds "You are my brother" (74).

x. According to the historical record, Homer and Langley's bodies were hidden by tons of garbage and were not found for weeks. Homer's body was found first lying among boxes and trash. Almost three weeks later the body of Langley was discovered just ten feet away from where his older brother had died.

xi. According to Fred Penzel, their family was "a branch of the well-known Livingstons. Their ancestors had come over to America on the ship 'Speedwell' in 1664, about a week after the Mayflower. The family had been members of the congregation of Trinity Church since 1697. Their father, Dr. Herman L. Collyer was a successful and renowned gynecologist, and his father, William Collyer, was said to have been one of the leading shipbuilders in America." Citing Robert Jarvis, Moran questions the validity of tracing the family's lineage back to the Pilgrims, attributing this piece of information to Langley's boasting $(276, \mathrm{ft} 6)$.

xii. For a detailed description of the vacant lot after the house's demolition to a "vest pocket park," see "Collyer Brothers Park" and "Homer \& Langley Collyer: Hoarders in Harlem."

xiii. See "E. L. Doctorow on His New Novel Homer \& Langley" in WNYC New York Public Radio.

xiv. As Moran suggests, "ghostly" is a characteristic usually attributed to the portrait of the hoarder. "The behavior, physical appearance, and living conditions of hoarders invite the rhetoric of the supernatural," he argues (275). Indeed, both the fictional and the historical Collyer brownstone are compared to a "haunted house" and a "ghost mansion."

xv. In his essay "Building, Dwelling, Thinking" (1953), Heidegger used the image of a cabin in the Black Forest to describe both building and dwelling. Heidegger's evocation of the peasant cabin 
in the Black Forest is almost exactly contemporary with Bachelard's evocation of the oneiric house as a way of opposing an encroaching modernity. See Henri Lefebvre's "Social Space" in The Production of Space 120-122.

xvi. I agree with Moran who contends that hoarders are stereotypically represented as "otherworldly precisely because they threaten the socially given ideologies and systems of value of the world to which they belong" (276). Nevertheless, Doctorow recontextualizes historical events in order to open possibilities for a resignification of the Collyer legend, one that sees them as subverting inherited notions of domesticity.

xvii. An uncanny detail of this event was that Duchamp's Fountain was photographed at Alfred Stieglitz's studio and the photo was published in The Blind Man.

xviii. The real Collyers lost their telephone service in 1917 and, eleven years later, their electricity, gas and water supply.

xix. Rachele Dini's book, Consumerism, Waste, and Re-Use in Twentieth-Century Fiction talks at length about how waste can provide a means of "living otherwise," exploring the radical potential of waste from the Surrealist texts of de Chirico, Breton, and Mina Loy up to Pynchon, and DeLillo.

xx. Direct references to Ralph Waldo Emerson's philosophy of self-reliance can be found on pages 127, 191, 196, 200. Another intertextual resonance the novel evokes is with Melville's novella "Bartleby, the Scrivener." The connection between the Collyers' and Bartleby's withdrawal was made by Doctorow himself in his interview to The Nation ("Balk Talk").

xxi. This significant change that Doctorow makes to the historical facts-to end his narrative in the late 1970s rather than in 1947 when the historical brothers died-serves two purposes: one is to make them become part of the 1960s decade and the other to emphasize their haunting presence in relation to American urban history. Besides, Doctorow's manipulations of American history are well documented; he was called a "literary time traveler" in Bruce Weber's article in The New York Times.

\section{ABSTRACTS}

In this paper, I analyze E. L. Doctorow's 2009 novel, Homer \& Langley, through the lens of Edgar Allan Poe's short story "The Fall of the House of Usher." While there has been a recurring claim about the significant similarities of Doctorow's work to some of the tales by Edgar Allan Poe, there has been no critical reading that draws the connection between this novel and Poe's famous tale. Doctorow deftly manipulates Poe's favorite gothic connection between architectural construction and the psychological experience of characters to explore notions of home and domesticity in an increasingly urban America through a reconfiguration of the legendary Homer and Langley Collyer. In Doctorow's novel, the Collyer brothers are not the obsessed hoarders or the models of American consumerism par excellence, as the urban myth describes them. On the contrary, they become paradigms of dwelling with alertness in the Heideggerian sense, the embodiment of an escapist mentality in a culture driven by mundane prosperity and social compliance. 
INDEX

Keywords: E.L. Doctorow, Edgar Allan Poe, "The Fall of the House of Usher, " Gothicism, domesticity 